Article

\title{
Antioxidant Properties of Polyphenolic Extracts from Quercus Laurina, Quercus Crassifolia, and Quercus Scytophylla Bark
}

\author{
Eréndira Valencia-Avilés ${ }^{1}$ (D) , Martha Estrella García-Pérez ${ }^{2}$, Ma. Guadalupe Garnica-Romo ${ }^{3}$, \\ Juan de Dios Figueroa-Cárdenas ${ }^{4}$, Esperanza Meléndez-Herrera ${ }^{5}$, Rafael Salgado-Garciglia ${ }^{6}$ \\ and Héctor E. Martínez-Flores ${ }^{2, *}$ \\ 1 Programa Institucional de Doctorado en Ciencias Biológicas, Universidad Michoacana de San Nicolás \\ Hidalgo, Ciudad Universitaria, Morelia, Michoacán CP 58030, Mexico; evalencia@umich.mx \\ 2 Facultad de Químico Farmacobiología, Universidad Michoacana de San Nicolás de Hidalgo, \\ Tzintzuntzan 173, Col. Matamoros, Morelia, Michoacán CP 58240, Mexico; margarc@live.ca \\ 3 Facultad de Ingeniería Civil, Universidad Michoacana de San Nicolás de Hidalgo, Ciudad Universitaria, \\ Morelia, Michoacán CP 58030, Mexico; ggarnica@umich.mx \\ 4 Centro de Investigación y Estudios Avanzados del Instituto Politécnico Nacional, Libramiento Norponiente \\ 2000, Fraccionamiento Realde Juriquilla, Querétaro, Qro CP 76230, Mexico; jfigueroa@cinvestav.mx \\ 5 Instituto de Investigaciones sobre Recursos Naturales, Universidad Michoacana de San Nicolás de Hidalgo, \\ Avenida San Juanito Itzícuaro SN, Morelia, Michoacán CP 58330, Mexico; emelendez@umich.mx \\ 6 Instituto de Investigaciones Químico Biológicas, Universidad Michoacana de San Nicolás de Hidalgo, \\ Ciudad Universitaria, Morelia, Michoacán CP 58030, Mexico; rsalgado@umich.mx \\ * Correspondence: hmartinez@umich.mx; Tel.: +52-(443)-314-2152
}

Received: 5 May 2018; Accepted: 19 June 2018; Published: 26 June 2018

\begin{abstract}
The objective of this work was to determine the concentration of total phenols, total flavonoids, hydroxycinnamic acids, and proanthocyanidins present in crude extracts of Quercus laurina, Q. crassifolia, and Q. scytophylla bark. They were extracted by ethanol $(90 \%)$ maceration and hot water. The antioxidant capacity was determined by the ability to capture $\mathrm{OH} \bullet, \mathrm{O}_{2} \bullet-$, $\mathrm{ROO} \bullet, \mathrm{H}_{2} \mathrm{O}_{2}$, $\mathrm{NO} \bullet$, and $\mathrm{HClO}$. The hot water crude extract of Q. crassifolia was chosen to be concentrated and purified due to its higher extraction yield (20.04\%), concentration of phenol compounds (747 $\mathrm{mg}$ gallic acid equivalent (GAE)/g, $25.4 \mathrm{mg}$ quercetin equivalent (QE)/g, $235 \mathrm{mg}$ ChAE/g, $25.7 \mathrm{mg}$ chlorogenic acid equivalents (ChAE)/g), and antioxidant capacity (expressed as half maximal effective concentration $\left(\mathrm{EC}_{50}, \mu \mathrm{g} / \mathrm{mL}\right): \mathrm{OH} \bullet=918, \mathrm{O}^{-} \bullet^{-}=80.5, \mathrm{ROO} \bullet=577, \mathrm{H}_{2} \mathrm{O}_{2}=597, \mathrm{NO} \bullet \geq 4000$, $\mathrm{HClO}=740$ ). In a second stage, $Q$. crassifolia extracted with hot water was treated with ethyl acetate, concentrating the phenol compounds $(860 \mathrm{mg} \mathrm{GAE} / \mathrm{g}, 43.6 \mathrm{mg} \mathrm{QE} / \mathrm{g}, 362 \mathrm{ChAE} / \mathrm{g}$, 9.4 cyanidin chloride equivalents $(\mathrm{CChE}) / \mathrm{g})$ and improving the scavenging capacity $\left(\mathrm{OH} \bullet=467, \mathrm{O}^{-} \bullet^{-}=58.1\right.$, $\mathrm{ROO} \bullet=716, \mathrm{H}_{2} \mathrm{O}_{2}=22.0, \mathrm{NO} \bullet \geq 4000, \mathrm{HClO}=108$ ). Q. crassifolia had the highest polyphenolic concentration and the better capacity for scavenging reactive species, being a favorable candidate to be considered in the development of new products.
\end{abstract}

Keywords: Quercus; oak bark; scavenging ability; polyphenols

\section{Introduction}

The genus Quercus, common name oak, belongs to the Fagaceae family. Oak is one of the most profitable economic woods used in the cooperage industry [1]; even the bark is utilized as stoppers. However, up to $25 \%$ of the bark has no application or is consumed as fuel [2]. The bark 
is then considered as waste, with scarce utilization, and sometimes the improvised ways of storage, elimination, or distribution can become an ecological and economic problem to be solved [3].

Some studies [4-6], reported that oak bark contains high concentrations of polyphenols. Structurally, phenolic compounds comprise an aromatic ring, bearing one or more hydroxyl substituents, and range from simple molecules to highly complex polymerized compounds [7]. More than 8000 phenolic structures are currently known, including phenolic acids (derivatives of benzoic acid and cinnamic acid), flavonoids, tannins (hydrolyzable and condensed), stilbenes, and lignans, among others [8]. In plant tissues, they are mainly present attached to sugars, although occasionally they are found as aglycones [9].

Since polyphenols are capable of scavenging reactive species, such as superoxide anions $\left(\mathrm{O}_{2} \bullet^{-}\right)$, hydroxyl $(\bullet \mathrm{OH})$, nitric oxide $(\mathrm{NO} \bullet)$, and alkyl peroxyl radicals $(\mathrm{ROO} \bullet)$, they are linked to the prevention of various diseases, by acting as antioxidants through electron-donating mechanisms [10]. Polyphenols have different types of pharmacological properties, including antioxidant, anti-inflammatory, antiproliferative, and hypolipidemic, and they also regulate redox potentials, metabolic disorders, and apoptosis [11].

Most research about the phenolic content and antioxidant properties of oak has been done on European and Asiatic species, mainly using leaves [12], twigs [13], acorns [14], and bark [15], and has shown that oak bark contains the highest concentration of total phenols, including tannins, proanthocyanidins, and flavonoids with strong anti-radical properties $[4,5,15]$.

Although Mexico is considered one of the most important countries regarding the diversity of oaks, with 150 species reported [16], and the traditional use of the bark in Mexican ethnic groups has been to treat different illnesses, like stomach ache, burns, infections, pain, etc. [17], the scientific information about Mexican oak species is scarce. Bark extract from Q. sideroxyla was determined to have a high concentration of total phenols, proanthocyanidins, and flavonoids, as well as strong antioxidant activity [3]. The chemical composition of sapwood, heartwood, and bark of the Mexican species Q. laurina and Q. crassifolia, was described, concluding that bark extract content for Q. crassifolia and Q. laurina was higher in comparison to other hardwood bark [6].

Bark oak polyphenols have been used for the development of functional foods, such as, the use of oak wood during the elaboration of barrels in the aging winemaking process, that contributes to increasing the polyphenol content of wines, due to the extraction of these compounds from oak wood [18]. Moreover, the preparation of drinks based on toasted acorn [19], honeydew honey of Q. pyrenaica [20], and infusions of oak leaves [21], show that oak is a good source of phenolic compounds, which can be extracted and used in the formulation of new functional products.

Oak bark from Mexican species represents an area of great interest for research, because it is a potential source of natural antioxidants [22]. The objective of this study was to determine the presence and amount of different groups of polyphenols in extracts from oak species Quercus crassifolia, Quercus laurina, and Quercus scytophylla, as well as their antioxidant capacity. We used two extraction methods, maceration with ethanol solution $(90 \%)$ and extraction with hot water. Also, we selected the oak (Q. crassifolia), which showed both the highest polyphenol yield and highest antioxidant capacity in the extracts to be purified with ethyl acetate, to obtain an extract rich in polyphenol compounds.

\section{Materials and Methods}

\subsection{Raw Material}

Bark of Q. crassifolia, Q. laurina, and Q. scytophylla was collected in a forestry plantation located in Ciudad Hidalgo, Michoacán, México. The three oak species were chosen due to their importance for the forestry industry in Michoacán. The leaves, flowers, and acorn were botanically identified by Pablo Cuevas Reyes, expert in forest botany of the Biology Faculty, Universidad Michoacana de San Nicolás de Hidalgo (UMSNH), and Emmanuel Pérez Calix, botanist of the "Institute of Ecology" in Patzcuaro, Michoacán. The bark was washed, cut into rectangles of about $5 \times 5 \mathrm{~cm}$, and dried at 
$40{ }^{\circ} \mathrm{C}$ for $48 \mathrm{~h}$. The bark was milled using a Thomas Digital ED-5 Wiley ${ }^{\circledR}$ cutting mill and sieved with \# 40 mesh $(400 \mu \mathrm{m})$.

\subsection{Polyphenol Crude Extracts}

\subsubsection{Extraction by Maceration}

The crude extraction of phenolic compounds was done by maceration [23]. Twenty grams of powder bark was added to $200 \mathrm{~mL}$ of a $90 \%$ ethanol solution, and agitated at $220 \mathrm{rpm}$ for $24 \mathrm{~h}$ at $22{ }^{\circ} \mathrm{C}$. The extract was filtered using Whatman ${ }^{\circ} 42$ paper, and the solids were washed with $200 \mathrm{~mL}$ of $90 \%$ ethanol. The crude extract was evaporated and then the solid residue was lyophilized (FreeZone 2.5 Liter Benchtop Freeze Dry System, Labconco ${ }^{\circledR}$, Kansas City, MO, USA) and stored in amber bottles at $4{ }^{\circ} \mathrm{C}$.

\subsubsection{Extraction by Hot Water}

Fifty grams of powder bark was used for the extraction with water $(2 \times 500 \mathrm{~mL})$ under reflux for $1 \mathrm{~h}$. The aqueous extract was filtered with Whatman 42 filter paper, lyophilized, and stored in dark bottles at $4{ }^{\circ} \mathrm{C}[23]$.

\subsection{Crude Extract Composition}

Total phenol, flavonoid, hydroxycinnamic acid, and proanthocyanidin content were determined in the crude extracts using spectrophotometric techniques. The results were compared with the commercial extract Oligopin ${ }^{\circledR}$ (Nutri-Dyn, Maple Plain, MN, USA), recognized for its antioxidant properties, as mentioned [24]. Total phenol content was determined following the method proposed by Scalbert et al. (1989), using a gallic acid calibration curve, and the absorbance was measured at $750 \mathrm{~nm}$ and the results were expressed as $\mathrm{mg}$ of gallic acid equivalent (GAE)/g of dried extract [25]. The flavonoid content was determined at $415 \mathrm{~nm}$ with the method of Brighente et al. (2007), using a calibration curve with quercetin used as standard. The results were expressed as $\mathrm{mg}$ of quercetin equivalent (QE)/g of dried extract [26]. The hydroxycinnamic acid content was determined by comparison with a calibration curve using chlorogenic acid as a standard, and the absorbance of the test was measured at $525 \mathrm{~nm}$, according to the method described in the European Pharmacopoeia [27], while the results were expressed as mg of chlorogenic acid equivalents (ChAE)/g of dried extract. Proanthocyanidin content was determined at $550 \mathrm{~nm}$, using cyanidin chloride as standard by the methodology proposed by Porter et al. (1996) [28]. The results were expressed as mg of cyanidin chloride equivalents (CChE)/g of dried extract.

\subsection{Antioxidant Capacity of Crude Extracts}

The antioxidant capacity of oak bark crude extracts was determined by spectrophotometric methods, considering the ability of extracts to capture oxidizing species of biological relevance. The percentage inhibition for hydrogen peroxide, nitric oxide, hypochlorous acid, superoxide, and hydroxyl was calculated using Equation (1), as reported by García-Pérez et al. (2010) [29]:

$$
\% \text { Scavenging }=100\left[\frac{A_{0}-\left(A_{1}-A_{2}\right)}{A_{0}}\right],
$$

where $A_{0}$ is the absorbance of the mixture without the extract, $A_{1}$ is the absorbance of the mixture with the extract, and $A_{2}$ is the absorbance of the extract.

Equation (2) was used to determine the percentage of peroxyl radical scavenging [29]:

$$
\% \text { Scavenging }=100\left[1-\frac{A_{e 0}-A_{e f}}{A_{c 0}-A_{c f}}\right],
$$


where, $A_{e 0}$ is the absorbance of the mixture without 2,2-diazobis(2-amidi-nopropane) dihydrochloride $(\mathrm{AAPH}), A_{c 0}$ is the control absorbance (absorbance of the mixture without extract or AAPH), $A_{e f}$ is the absorbance of the mixture with extract and $\mathrm{AAPH}$, and $A_{c f}$ is the absorbance of the mixture without the extract.

In all cases, the effective concentration $\left(\mathrm{EC}_{50}\right)$ was calculated, defined as the amount of extract required until reduced by $50 \%$ of the concentration of the reactive species. The antioxidant capacity of extracts was compared to that of Oligopin ${ }^{\circledR}$ and turmeric Terana ${ }^{\circledR}$ (Terana S.A., Ciudad de México, México) taken as positive controls. All analyses were done in triplicate.

\subsubsection{Superoxide Anion Radical $\left(\mathrm{O}_{2} \bullet^{-}\right)$Scavenging Activity}

The ability of the extracts to capture superoxide radicals $\left(\mathrm{O}_{2} \bullet^{-}\right)$was measured [30], using one milliliter of nitroblue tetrazolium $[100 \mu \mathrm{M}]$ mixed with $1 \mathrm{~mL}$ of Nicotinamide adenine dinucleotide $\mathrm{NADH}[468 \mu \mathrm{M}]$ and $1 \mathrm{~mL}$ of extract. The reaction was initiated with $150 \mu \mathrm{L}$ of phenazine methosulfate. The solution was incubated at $30^{\circ} \mathrm{C}$ for $30 \mathrm{~min}$, and the absorbance of the solutions was measured [30].

\subsubsection{Hydrogen Peroxide $\left(\mathrm{H}_{2} \mathrm{O}_{2}\right)$ Scavenging Activity}

The capability of extracts to scavenge $\mathrm{H}_{2} \mathrm{O}_{2}$ reactive species was calculated following the procedure described by Ruch et al. (1989). In test tubes, $1.7 \mathrm{~mL}$ of the extract solution, in concentrations between 0.5 and $1500 \mu \mathrm{g} / \mathrm{mL}$, plus $300 \mu \mathrm{L}$ of $\mathrm{H}_{2} \mathrm{O}_{2}$ solution $(40 \mathrm{mM})$ was added, and maintained at $22{ }^{\circ} \mathrm{C}$ for $3 \mathrm{~min}$. The absorbance was measured at $230 \mathrm{~nm}$ [31].

\subsubsection{Hydroxyl Radical $(\mathrm{OH} \bullet)$ Scavenging Activity}

The antiradical activity of the extracts against hydroxyl radicals was determined as reported by Smirnoff \& Cumbes (1989). One milliliter of the extract solution was added to dimethyl sulfoxide at different concentrations (ranging from 100 to $2000 \mu \mathrm{g} / \mathrm{mL}$ ), $300 \mu \mathrm{L} \mathrm{FeSO}_{4}\left(8 \mathrm{mM}\right.$ ), and $250 \mu \mathrm{L}$ of $\mathrm{H}_{2} \mathrm{O}_{2}$ $(20 \mathrm{mM})$. The reaction was initiated by addition of $1 \mathrm{~mL}$ of salicylic acid solution $(3 \mathrm{mM})$, and then was incubated for $30 \mathrm{~min}$ at $30^{\circ} \mathrm{C}$. After that, $450 \mu \mathrm{L}$ of distilled water was added, and the mixture was centrifuged for $10 \mathrm{~min}$ at $3500 \mathrm{rpm}$, the supernatant recovered and the absorbance measured at a wavelength of $510 \mathrm{~nm}$ [32].

\subsubsection{Nitric Oxide Radical (NO•) Scavenging Activity}

The nitric oxide radical scavenging activity was analyzed according to the method indicated by Sreejayan \& Rao (1997) where $0.5 \mathrm{~mL}$ aliquot of extract between 100 and $2500 \mu \mathrm{g} / \mathrm{mL}$ was mixed with $0.5 \mathrm{~mL}$ of $10 \mathrm{mM}$ sodium nitroprusside, and placed in a water bath at $37^{\circ} \mathrm{C}$ for $2.5 \mathrm{~h}$. After that, the samples were maintained at $22^{\circ} \mathrm{C}$ for $20 \mathrm{~min}$, then $1 \mathrm{~mL}$ of Griess reagent was added; the mixture was kept for $40 \mathrm{~min}$ at $22^{\circ} \mathrm{C}$, and maintained for $20 \mathrm{~min}$ in the dark. The absorbance was measured at $548 \mathrm{~nm}[33]$.

\subsubsection{Peroxyl Radical (ROO•) Scavenging Activity}

The ability to capture peroxyl radicals (ROO•) was determined by using the pyrogallol red $(1.5 \mathrm{~mL})$ as a target oxidized molecule and AAPH $(25 \mu \mathrm{L}, 600 \mathrm{mM})$ as a peroxyl radical generator like López-Alarcón \& Lissi (2005). A $150 \mu \mathrm{L}$ aliquot of extract was added at concentrations between $100 \mu \mathrm{g} / \mathrm{mL}$ and $1500 \mu \mathrm{g} / \mathrm{mL}$. The oxidized pyrogallol red was measured at $540 \mathrm{~nm}$ [34].

\subsubsection{Hypochlorous Acid ( $\mathrm{HClO})$ Scavenging Activity}

The capacity to scavenge hypochlorous acid was measured using the methodology described by Aruoma \& Halliwell (1987) with some modifications. One milliliter of the extract, between 100 and $2500 \mu \mathrm{g} / \mathrm{mL}$, was mixed with $1 \mathrm{~mL}$ of $\mathrm{HClO}(14.3 \mathrm{mM})$ in phosphate-buffered saline (PBS). The mixture 
was incubated at $37^{\circ} \mathrm{C}$ for $15 \mathrm{~min}$. Then, $222.22 \mu \mathrm{L}$ of catalase (400 U) was added, and the mixture was incubated for $15 \mathrm{~min}$ at $37^{\circ} \mathrm{C}$. The absorbance was measured at $240 \mathrm{~nm}$ [35].

\subsection{Liquid-Liquid Purification of the Most Antioxidant Extract Selected: Composition and Antioxidant Capacity of the Purified Extract}

The crude extract of Q. crassifolia was chosen to be purified and concentrated, because it was shown to have the best extraction yield, higher polyphenol concentration, and better capacity to scavenge reactive species. A liquid-liquid extraction was done as follows [7]. Six grams of lyophilized extract was suspended in $100 \mathrm{~mL}$ of water and filtered with a Gooch crucible. The solution was defatted with hexane $(5 \times 100 \mathrm{~mL})$, and then the polyphenols were concentrated with ethyl acetate $(5 \times 100 \mathrm{~mL})$. This solvent was evaporated, resuspended in water and lyophilized. The percentage extraction as well as the total phenol, total flavonoid, hydroxycinnamic acid, and proanthocyanidin content was determined for the purified extract. Also, the antioxidant capacity of the extract to scavenge different reactive species (hydrogen peroxide, nitric oxide, hypochlorous acid, as well as hydroxyl, superoxide, and peroxyl radicals) was analyzed.

\subsection{Statistical Analysis}

The experimental results were expressed as mean \pm standard error (SE) of three replicates. Results were analyzed by analysis of variance (ANOVA) $(p<0.05)$, and means separated by Duncan's test. Spearman's correlation test was used for correlations $(p<0.05)$. Student's t-test was used to analyze differences in content of phenolic compounds and the antioxidant capacity of the crude and purified extract. Statistical analysis was done using STATISTICA 7.0 software (TIBCO Software Inc, Palo Alto, CA, USA) [36].

\section{Results and Discussion}

\subsection{Yields and Chemical Composition of Crude Extracts from Quercus sp.}

The extraction yields of the crude extracts obtained by the two extraction methods for the three different Quercus sp. are shown in Table 1. There were no significant differences $(p<0.05)$ between the extraction method using hot water compared to the maceration method for $Q$. laurina and Q. scytophylla. Extract from Q. crassifolia using hot water had the highest extraction yield, 20.0\% $w / w$ dry bark. These differences can be explained by the different polarity of the compounds present in the species of Quercus sp.

Table 1. Extraction yields of crude and purified extracts from Mexican oak species obtained by hot water and maceration methods.

\begin{tabular}{ccc}
\hline Extract & Extraction Method & \% Extraction Yield (w/w Dry Bark) \\
\hline Quercus crassifolia & Hot water & $20.0 \pm 7.7^{\mathrm{a}}$ * \\
Purified Quercus crassifolia & Hot water & $2.7 \pm 0.3$ \\
Quercus crassifolia & Maceration & $11.0 \pm 1.0^{\mathrm{b}, \mathrm{c}}$ \\
Quercus laurina & Hot water & $14.2 \pm 0.2^{\mathrm{b}}$ \\
Quercus laurina & Maceration & $13.6 \pm 0.1^{\mathrm{b}}$ \\
Quercus scytophylla & Hot water & $6.8 \pm 1.9^{\mathrm{c}, \mathrm{d}}$ \\
Quercus scytophylla & Maceration & $4.4 \pm 0.2^{\mathrm{d}}$ \\
\hline
\end{tabular}

\footnotetext{
$+\%\left(w / w\right.$ dry bark). Means with different letters $\left({ }^{\mathrm{a}}, \mathrm{b}, \mathrm{c}, \mathrm{d}\right)$ in the same column are significantly different at $p<0.05$ (ANOVA, followed by Duncan's test). Means with * in the same column are different at $p<0.05$ (Student's $t$-test, comparing crude and purified $Q$. crassifolia hot water extracts).
}

The total phenol, flavonoid, hydroxycinnamic acid, and proanthocyanidin content is shown in Table 2. The concentration of total phenols followed the order: $Q$. laurina exposed to the maceration method (756 mg GAE/g), Q. crassifolia exposed to the hot water method (746 mg GAE/g) and 
Q. crassifolia exposed to the maceration method (694 GAE/g). There were no significant differences $(p<0.05)$ between treatments, and values were similar to those obtained for the Oligopin ${ }^{\circledR}$ sample (735 mg GAE/g). For total flavonoid content, extraction with hot water led to the highest total flavonoid content in Q. crassifolia (25.4 mg QE/g), four times higher than the Oligopin ${ }^{\circledR}$ value $(6.4 \mathrm{mg} \mathrm{QE} / \mathrm{g})$. The highest value for proanthocyanidin compounds was observed in the $Q$. crassifolia extract obtained by maceration $(53.5 \mathrm{mg} \mathrm{CChE} / \mathrm{g})$, significantly different $(p<0.05)$ from the other treatments and lower than that obtained for Oligopin ${ }^{\circledR}(69.2 \mathrm{mg} \mathrm{CChE} / \mathrm{g})$. The best extraction yields for hydroxycinnamic acids and proanthocyanidins were obtained when the maceration method was used. Our results are in agreement with those results described by García-Pérez et al. (2010), where the relationship between the extracts made both by maceration and with hot water was studied in different barks of Canadian wood species.

Table 2. Total phenol, total flavonoid, total hydroxycinnamic acid, and proanthocyanidin content of Mexican Quercus species extracts obtained by hot water and maceration methods.

\begin{tabular}{|c|c|c|c|c|}
\hline Extract & $\begin{array}{l}\text { Total Phenols } \\
\text { (mg GAE/g) }\end{array}$ & $\begin{array}{l}\text { Total Flavonoids } \\
\text { (mg QE/g) }\end{array}$ & $\begin{array}{l}\text { Hydroxycinnamic } \\
\text { Acids (mg ChAE/g) }\end{array}$ & $\begin{array}{l}\text { Proanthocyanidins } \\
\text { (mg CChE/g) }\end{array}$ \\
\hline $\begin{array}{l}\text { Q. crassifolia } \\
\text { hot water }\end{array}$ & $747 \pm 41^{\mathrm{a}}$ & $25.4 \pm 0.6^{\mathrm{a}}$ & $235 \pm 2^{c}$ & $25.7 \pm 1.3^{d *}$ \\
\hline $\begin{array}{c}\text { Purified Q. crassifolia } \\
\text { hot water }\end{array}$ & $860 \pm 6^{*}$ & $43.6 \pm 0.3 *$ & $362 \pm 13 *$ & $9.4 \pm 0.3$ \\
\hline $\begin{array}{l}\text { Q. crassifolia } \\
\text { maceration }\end{array}$ & $695 \pm 62^{a}$ & $14.0 \pm 0.3^{d}$ & $269 \pm 37^{b}$ & $53.5 \pm 1.0^{\mathrm{b}}$ \\
\hline $\begin{array}{l}\text { Q. laurina } \\
\text { hot water }\end{array}$ & $474 \pm 44^{\mathrm{b}}$ & $24.1 \pm 1.1^{b}$ & $133 \pm 4^{\mathrm{e}, \mathrm{f}}$ & $14.2 \pm 0.4^{\mathrm{e}}$ \\
\hline $\begin{array}{l}\text { Q. laurina } \\
\text { maceration }\end{array}$ & $756 \pm 17^{\mathrm{a}}$ & $15.7 \pm 0.2^{\mathrm{e}}$ & $145 \pm 17^{\mathrm{e}, \mathrm{f}}$ & $24.3 \pm 1.8^{\mathrm{d}}$ \\
\hline $\begin{array}{l}\text { Q. scytophylla } \\
\text { hot water }\end{array}$ & $329 \pm 38^{c}$ & $24.1 \pm 0.5^{b}$ & $113 \pm 3^{\mathrm{e}, \mathrm{f}}$ & $12.6 \pm 2.3^{\mathrm{e}}$ \\
\hline $\begin{array}{l}\text { Q. scytophylla } \\
\text { maceration }\end{array}$ & $521 \pm 40^{b}$ & $12.9 \pm 0.3^{c}$ & $173 \pm 13^{d, e}$ & $48.4 \pm 3.8^{c}$ \\
\hline Oligopin ${ }^{\circledR}$ & $736 \pm 20^{a}$ & $6.4 \pm 0.2^{f}$ & $337 \pm 28^{a}$ & $69.2 \pm 0.8^{a}$ \\
\hline
\end{tabular}

Means with different letters $(\mathrm{a}, \mathrm{b}, \mathrm{c}, \mathrm{d}, \mathrm{e}, \mathrm{f}$ ) in the same column are significantly different at $p<0.05$ (ANOVA, followed by Duncan's test). GAE, gallic acid equivalents; QE, quercetin equivalents; ChAE, chlorogenic acid equivalents; CChE, cyanidin chloride equivalents. Means with * in the same column are different at $p<0.05$ (Student's $t$-test, comparing crude and purified Q. crassifolia hot water extracts).

In agreement with those results described by García-Pérez et al. (2010) and Naima et al. (2015), in the first one, compared the relationship between maceration and hot water extraction for different barks of Canadian wood species. In another investigation, Naima et al. (2015), showed that the increase of the extract temperature improves the yield of polyphenols and hydrolyzable tannins extracted with hot water from Acacia mollissima bark [29,37].

The lower content of hydroxycinnamic acids and proanthocyanidins in Michoacán oak species compared to the commercial extract Oligopin ${ }^{\circledR}$ could be due to analysis of the extracts in crude form, which must contain highly polar compounds (e.g., sugars), non-selectively extracted using these extraction methods, unlike the extract Oligopin ${ }^{\circledR}$, which represents the ethyl acetate fraction of the aqueous extract of French maritime pine bark.

For this reason, we decided to purify the extract obtained by the hot water method for Q. crassifolia, the species with the highest solids yield. This purification was done with ethyl acetate. The results showed that the fraction purified with ethyl acetate had the highest values for total phenols (860 mg GAE/g), flavonoids (43.6 mg QE/g), and hydroxycinnamic acids (362 mg ChAE/g) compared to the other species (Table 2), regardless of the extraction method used. Even greater values were obtained than for the commercial extract Oligopin ${ }^{\circledR}$. Only the proanthocyanidin value was lower in the purified Q. crassifolia ethyl acetate extract compared to all other species, regardless of the method used. 


\subsection{Antioxidant Capacity of Crude Extracts from Quercus sp.}

The antioxidant capacity values of crude extracts of the oak species obtained by maceration and hot water, as well as the Oligopin ${ }^{\circledR}$ and Terana ${ }^{\circledR}$ turmeric, considering their ability to capture species of biological relevance, such as hydroxyl, superoxide and peroxyl radicals, hydrogen peroxide, nitric oxide, and hypochlorous acid, is shown in Table 3.

Table 3. Free radical scavenging of Quercus sp. bark hot water and ethanolic extracts.

\begin{tabular}{|c|c|c|c|c|c|c|}
\hline Extract & $\begin{array}{c}\mathrm{OH} \bullet \\
\mathrm{EC}_{50}(\mu \mathrm{g} / \mathrm{mL})\end{array}$ & $\begin{array}{c}\mathrm{O}_{2} \bullet^{-} \\
\mathrm{EC}_{50}(\mu \mathrm{g} / \mathrm{mL})\end{array}$ & $\begin{array}{c}\text { ROO• } \\
\mathrm{EC}_{50}(\mu \mathrm{g} / \mathrm{mL})\end{array}$ & $\begin{array}{c}\mathrm{H}_{2} \mathrm{O}_{2} \\
\mathrm{EC}_{50}(\mu \mathrm{g} / \mathrm{mL})\end{array}$ & $\begin{array}{c}\text { NO• } \\
\mathrm{EC}_{50}(\mu \mathrm{g} / \mathrm{mL})\end{array}$ & $\begin{array}{c}\mathrm{HClO} \\
\mathrm{EC}_{50}(\mu \mathrm{g} / \mathrm{mL})\end{array}$ \\
\hline $\begin{array}{l}\text { Q. crassifolia } \\
\text { hot water }\end{array}$ & $918 \pm 9^{c *}$ & $80.5 \pm 0.7^{\mathrm{e} *}$ & $577 \pm 40^{\mathrm{c}}$ & $597 \pm 162^{b *}$ & $>4000^{a *}$ & $740 \pm 54^{b *}$ \\
\hline $\begin{array}{c}\text { Purified Q. crassifolia } \\
\text { hot water }\end{array}$ & $467 \pm 50$ & $58.1 \pm 1.6$ & $717 \pm 9 *$ & $22.0 \pm 1.8$ & $>4000 *$ & $108 \pm 25$ \\
\hline $\begin{array}{l}\text { Q. crassifolia } \\
\text { maceration }\end{array}$ & $2024 \pm 198^{b}$ & $40.9 \pm 16.4^{\mathrm{e}}$ & $1747 \pm 87^{a}$ & $653 \pm 122^{b}$ & $873 \pm 49^{b}$ & $1276 \pm 40^{\mathrm{a}}$ \\
\hline $\begin{array}{l}\text { Q. laurina } \\
\text { hot water }\end{array}$ & $1257 \pm 75^{c}$ & $629 \pm 9^{c}$ & $582 \pm 15^{c}$ & $727 \pm 57^{b}$ & $>4000^{a}$ & $774 \pm 192^{b}$ \\
\hline $\begin{array}{c}\text { Q. laurina } \\
\text { maceration }\end{array}$ & $>4000^{\mathrm{a}}$ & $3213 \pm 917^{b}$ & $622 \pm 48^{c}$ & $519 \pm 116^{b}$ & $149 \pm 17^{\mathrm{d}}$ & $387 \pm 86^{c}$ \\
\hline $\begin{array}{l}\text { Q. scytophylla } \\
\text { hot water }\end{array}$ & $1865 \pm 396^{b}$ & $>4000^{a}$ & $390 \pm 160^{d}$ & $1102 \pm 49^{a}$ & $>4000^{a}$ & $866 \pm 183^{b}$ \\
\hline $\begin{array}{l}\text { Q. scytophylla } \\
\text { maceration }\end{array}$ & $>4000^{a}$ & $406 \pm 135^{d}$ & $856 \pm 24^{b}$ & $1050 \pm 166^{a}$ & $661 \pm 177^{c}$ & $953 \pm 212^{b}$ \\
\hline Oligopin ${ }^{\circledR}$ & $1271 \pm 72^{c}$ & $104 \pm 8^{\mathrm{e}}$ & $563 \pm 33^{c}$ & $174 \pm 10^{c}$ & $>4000^{a}$ & $1310 \pm 114^{a}$ \\
\hline $\begin{array}{l}\text { Terana }^{\circledR} \\
\text { turmeric }\end{array}$ & & & & & $53.8 \pm 39.0^{\mathrm{d}}$ & \\
\hline
\end{tabular}

Means with different letters $\left({ }^{a}, b, c, d, e\right)$ in the same column are significantly different at $p<0.05$ (ANOVA, followed by Duncan's test). $\mathrm{OH} \bullet ; \mathrm{O}_{2} \bullet^{-}$; $\mathrm{ROO} \bullet ; \mathrm{H}_{2} \mathrm{O}_{2} ; \mathrm{NO} \bullet ; \mathrm{HClO}$. Means with ${ }^{*}$ in the same column are different at $p<0.05$ (Student's $t$-test, comparing crude and purified Q. crassifolia hot water extracts). EC En $_{5}$ half maximal effective concentration.

This chemical characterization provides information on the chemical reactivity of the phenolic crude extracts for different free radicals and reactive species. The $\mathrm{EC}_{50}$ values showed that $Q$. crassifolia extracts, obtained both by maceration and hot water, had the best ability to capture superoxide anions (40.9 and $80.5 \mu \mathrm{g} / \mathrm{mL}$, respectively), while Q. crassifolia extracted with hot water showed the best ability to capture hydroxyl radicals $(918 \mu \mathrm{g} / \mathrm{mL})$, better even than Oligopin ${ }^{\circledR}(1271 \mu \mathrm{g} / \mathrm{mL})$. Q. scytophylla extracted with hot water had the best ability to capture peroxyl radicals $(390 \mu \mathrm{g} / \mathrm{mL})$, followed by Q. crassifolia $(577 \mu \mathrm{g} / \mathrm{mL})$ and Q. laurina extracted with hot water $(582 \mu \mathrm{g} / \mathrm{mL})$, which had similar values to Oligopin ${ }^{\circledR}(563 \mu \mathrm{g} / \mathrm{mL})$.

However, Q. scytophylla extracts showed a lower ability to capture other reactive species compared to the other extracts. No differences in ability to capture $\mathrm{H}_{2} \mathrm{O}_{2}$ were found for $Q$. crassifolia extracted with hot water, $Q$. crassifolia by maceration, $Q$. laurina with hot water, and $Q$. laurina by maceration $(p<0.05)$.

The ability of the extracts to capture nitric oxide was evaluated at the same time with Terana ${ }^{\circledR}$ turmeric extract (Terana S.A.) obtained from dried rhizomes of Curcuma longa, a material of golden color, used worldwide as a food additive. Some studies have been done in recent years related to the biological activity of curcumin, including its antioxidant, antifungal, antitumor, anti-inflammatory, and antibacterial properties, attributed to its high ability to capture nitric oxide [38]. The turmeric extract showed the best ability to capture nitric oxide $(53.8 \mu \mathrm{g} / \mathrm{mL})$, followed by Q. laurina extracted by maceration $(149 \mu \mathrm{g} / \mathrm{mL})$.

As for the ability to inhibit hypochlorous acid, $Q$. laurina extracted by maceration had the best antioxidant capacity $(387 \mu \mathrm{g} / \mathrm{mL})$, followed by Q. crassifolia $(740 \mu \mathrm{g} / \mathrm{mL})$, and Q. laurina extracted with hot water $(774 \mu \mathrm{g} / \mathrm{mL})$. 
As we can see, the overall results highlighted that the extracts of $Q$. crassifolia obtained with hot water and Q. laurina by maceration had the highest efficiency to capture the different radicals; however, Q. crassifolia had a higher extraction yield (Table 1).

To identify association of the distinct kinds of polyphenolic content with antioxidant activity, a Spearman correlation analysis was performed (Table 4). The capacity to capture superoxide radicals was related to both hydroxycinnamic acid $(r=-0.829, p=0.001)$ and total phenolic $(r=-0.567$, $p=0.004)$ compounds. These results are in agreement with those reported by Natić et al. (2015), who found that the polyphenols present in mulberry fruits grown in Vojvodina possess high antioxidant-antiradical activity, acting as potent superoxide anion radical scavengers; the predominant phenolic acids were protocatechuic acid and ferulic acid, showing high positive correlation with their ability to scavenge superoxide anion radicals [39].

Table 4. Spearman coefficient for correlation between the scavenging capacity of the reactive species and the phenolic compound content.

\begin{tabular}{|c|c|c|c|c|c|c|}
\hline & ROO• & $\mathrm{O}_{2} \bullet-$ & $\mathrm{OH \bullet}$ & $\mathrm{H}_{2} \mathrm{O}_{2}$ & NO• & $\mathrm{HClO}$ \\
\hline Total phenols & 0.298 & $-0.567 *$ & $-0.441 *$ & $-0.821 *$ & -0.070 & -0.411 \\
\hline Total flavonoids & -0.005 & -0.223 & $-0.631 *$ & -0.119 & $0.511 *$ & $-0.532 *$ \\
\hline Total hydroxycinnamic acids & 0.403 & $-0.829 *$ & $-0.545 *$ & $-0.835 *$ & 0.186 & 0.023 \\
\hline Proanthocyanidins & -0.261 & -0.245 & 0.324 & -0.056 & -0.331 & $0.687 *$ \\
\hline
\end{tabular}

The flavonoid $(r=-0.631, p=0.001)$ and total phenol $(r=-0.441, p=0.035)$ content in the extracts correlated with the ability to capture hydroxyl radicals, as found in the Matricaria pubescens extracts [40]; their results revealed significant correlation between the phenolic and flavonoid compound content and antioxidant activity assessed by hydroxyl radical scavenging capacity.

The hydrogen peroxide radical scavenging activity was more strongly associated with total phenols $(r=-0.821, p=0.002)$ than hydroxycinnamic acids $(r=-0.545, p=0.007)$. The ability of Canadian wood species extracts to scavenge $\mathrm{H}_{2} \mathrm{O}_{2}$ was also associated with total phenol content [29].

The concentration of total flavonoids and the proanthocyanidin content correlated with their ability to capture hypochlorous acid, $r=-0.532(p=0.009)$ and $r=0.687(p=0.0002)$, respectively. Also demonstrated, was a high association between flavonoid compounds and antioxidant activity in extracts from buckwheat hulls and flour [41]. In our study, total flavonoid concentration was correlated with the ability to capture nitric oxide $(r=0.511, p=0.013)$. That means that a high concentration of both proanthocyanidins and total flavonoids shows a greater ability to capture hypochlorous acid and nitric oxide.

\subsection{Chemical Composition and Antioxidant Capacity of Purified Q. crassifolia Extract}

As previously mentioned, the Q. crassifolia extract obtained by the hot water method was, in turn, subjected to a subsequent extraction with ethyl acetate. This extract, from now on called purified, was analyzed to determine the content of its diverse groups of phenolic compounds and their antioxidant capacity, as shown in Tables 2 and 3. The extraction yield of the purified Q. crassifolia decreased considerably compared to the extraction yield of crude extract of $Q$. crassifolia using the hot water method. This is reasonable because we concentrated the compounds, obtaining only the fraction corresponding to those compounds that are soluble in ethyl acetate.

A higher concentration of total phenols, total flavonoids and hydroxycinnamic acids was observed in the purified Q. crassifolia extract compared to crude extract of $Q$. crassifolia obtained using the hot water method (Table 2); however, the purified extract showed a lower proanthocyanidin content, consistent with the study done by Quettier-Deleu et al. (2000) [41], which also described a higher total phenol content and lower proanthocyanidin content in an ethyl acetate extract of Picea mariana bark compared to the aqueous fraction extract. This result can be explained if we consider that the aqueous 
fraction, which is discarded during the purification step, contains mainly polymeric proanthocyanidins, whereas the ethyl acetate fraction is mainly composed of oligomeric proanthocyanidins. Notably, it has been shown that oligomeric proanthocyanidins, due to their lower molecular weight, possess greater biological activity than polymeric compounds. In fact, these latter, because of their large size, are unable to cross biological membranes, and therefore, cannot interfere with the signaling pathways related to disease pathogenesis [42].

The purified extract had improved ability to capture hydroxyl radicals, superoxide anions, hydrogen peroxide, and hypochlorous acid, while for peroxyl radicals, the purified extract had an increased $\mathrm{EC}_{50}$ value compared to crude extracts. This may be due to loss in the aqueous fraction of compounds that may be related to the ability to capture peroxyl radicals, such as polymeric proanthocyanidins, hydrolyzable tannins and lignans, among others, which had not been determined in this work.

In general, the purified extract had a better antioxidant capacity compared to the aqueous extract of Q. crassifolia. With regard to nitric oxide radicals, neither crude nor purified extracts, at concentrations less than $4000 \mathrm{mg} / \mathrm{mL}$, had ability to capture the nitrogen reactive species.

\section{Conclusions}

In this research, a high concentration of total phenols was found in the Quercus sp. bark crude extracts, including different classes of phenolic compounds, like flavonoids, hydroxycinnamic acids, and proanthocyanidins, confirming that the Mexican species oak barks analyzed in this work are a good source of phenolic compounds.

There were no differences in the content of total phenols or hydroxycinnamic acids between purified extract of Q. crassifolia and Oligopin ${ }^{\circledR}$, and actually, for concentration of flavonoids, the purified extract of $Q$. crassifolia had a higher concentration. Regarding the antioxidant capacity, the purified extract showed, in general, better antioxidant characteristics than Oligopin ${ }^{\circledR}$, being a good candidate to be considered in the development of new products with high antioxidant activity, however, further studies are necessary to determine the chemical composition of the extract, as well as the toxicological profile, in order to have a better understanding about its possible applications.

Author Contributions: H.E.M.-F. and M.E.G.-P. conceived and designed the experiments, E.V.-A. performed the experiments, M.G.G.-R., J.d.D.F.-C., R.S.-G. and E.M.-H. discuss and analyzed some of the data obtained during the experiments. All authors revised the paper and approved the final manuscript.

Acknowledgments: The authors wish to thank CONACyT for the Ph.D. scholarship of Eréndira Valencia Avilés. This project was partially supported with equipment UV/Vis spectrophotometer acquired through "Redes Temáticas de Colaboración Académica, Tercer año aprobado en la convocatoria 2011 (Marzo 2015), PRODEP", Red Materiales Nanoestructurados, Proyecto "Investigación y Desarrollo de Conductores Transparentes".

Conflicts of Interest: The authors declare no conflict of interest.

\section{References}

1. Castro-Vázquez, L.; Alañón, M.E.; Ricardo-da-Silva, J.M.; Pérez-Coello, M.S.; Laureano, O. Evaluation of Portuguese and Spanish Quercus pyrenaica and Castanea sativa species used in cooperage as natural source of phenolic compounds. Eur. Food Res. Technol. 2013, 237, 367-375. [CrossRef]

2. Aroso, I.M.; Fernandes, E.M.; Pires, R.A.; Mano, J.F.; Reis, R.L. Cork extractives exhibit thermo-oxidative protection properties in polypropylene-cork composites and as direct additives for polypropylene. Polym. Degrad. Stab. 2015, 116, 45-52. [CrossRef]

3. Rosales-Castro, M.; González-Laredo, R.F.; Rocha-Guzman, N.E.; Gallegos-Infante, J.A.; Rivas-Arreola, M.J.; Karchesy, J.J. Antioxidant activity of fractions from Quercus sideroxyla bark and identifi cation of proanthocyanidins by HPLC-DAD and HPLC-MS. Holzforschung 2012, 66, 577-584. [CrossRef]

4. Sroka, Z.; Franiczek, R. Antiradical and Antimicrobial Activity of Extracts Obtained from Plant Raw Materials. Adv. Clin. Exp. Med. 2008, 17, 275-283. 
5. Dróżdż, P.; Pyrzynska, K. Assessment of polyphenol content and antioxidant activity of oak bark extracts. Eur. J. Wood Wood Prod. 2018, 7, 793-795. [CrossRef]

6. Ruiz-Aquino, F.; González-Peña, M.M.; Valdez-Hernández, J.I.; Revilla, U.S.; Romero-Manzanares, A. Chemical Characterization and Fuel Properties of Wood and Bark of Two Oaks from Oaxaca, Mexico. Ind. Crops Prod. 2015, 65, 90-95. [CrossRef]

7. Stevanovic, T.; Diouf, P.N.; Garcia-Perez, M.E. Bioactive Polyphenols from Healthy Diets and Forest Biomass. Curr. Nutr. Food Sci. 2009, 5, 264-295. [CrossRef]

8. Garrido, J.; Borges, F. Wine and grape polyphenols-A chemical perspective. Food Res. Int. 2013, 54, 1844-1858. [CrossRef]

9. Duda-Chodak, A. The inhibitory effect of polyphenols on human gut microbiota. J. Physiol. Pharmacol. 2012, 63, 497-503. [PubMed]

10. Lü, J.-M.; Lin, P.H.; Yao, Q.; Chen, C. Chemical and molecular mechanisms of antioxidants: Experimental approaches and model systems. J. Cell. Mol. Med. 2010, 14, 840-860. [CrossRef] [PubMed]

11. Upadhyay, S.; Dixit, M. Role of polyphenols and other phytochemicals on molecular signaling. Oxid. Med. Cell. Longev. 2015, 2015, 504253. [CrossRef] [PubMed]

12. He, Y.-Q.; Ma, Z.-Y.; Zhang, J.; Du, B.-Z.; Yao, B.-H. Antioxidant activity of the chemical constituents from the leaves of Quercus macrocarpa. Chem. Nat. Compd. 2011, 47, 472-473. [CrossRef]

13. Popovic, B.M.; Štajner, D.; Zdero, R.; Orlovi, S.; Galic, Z. Antioxidant Characterization of Oak Extracts Combining Spectrophotometric Assays and Chemometrics. Sci. World J. 2013, 2013, 134656. [CrossRef] [PubMed]

14. Custódio, L.; Patarra, J.; Alberício, F.; Neng, N.R.; Nogueira, J.M.F.; Romano, A. Extracts from Quercus sp. acorns exhibit in vitro neuroprotective features through inhibition of cholinesterase and protection of the human dopaminergic cell line SH-SY5Y from hydrogen peroxide-induced cytotoxicity. Ind. Crops Prod. 2013, 45, 114-120. [CrossRef]

15. Söhretoğlu, D.; Sabuncuoğlu, S.; Harput, U.Ş. Evaluation of antioxidative, protective effect against $\mathrm{H}_{2} \mathrm{O}_{2}$ induced cytotoxicity, and cytotoxic activities of three different Quercus species. Food Chem. Toxicol. 2012, 50, 141-146. [CrossRef] [PubMed]

16. Vázquez, L.M.; Valencia, A.S.; Nixon, K.C. Notes on red oaks (Quercus sect. Lobatae) in eastern Mexico, with description of a new species, Quercus hirtifolia. Brittonia 2004, 56, 136-142. [CrossRef]

17. Sánchez-Burgos, J.A.; Ramírez-Mares, M.V.; Larrosa, M.M.; Gallegos-Infante, J.A.; González-Laredo, R.F.; Medina-Torres, L.; Rocha-Guzmán, N.E. Antioxidant, antimicrobial, antitopoisomerase and gastroprotective effect of herbal infusions from four Quercus species. Ind. Crops Prod. 2013, 42, 57-62. [CrossRef]

18. Alañón, M.E.; Castro-Vázquez, L.; Díaz-Maroto, M.C.; Hermosín-Gutiérrez, I.; Gordon, M.H.; Pérez-Coello, M.S. Antioxidant capacity and phenolic composition of different woods used in cooperage. Food Chem. 2011, 129, 1584-1590. [CrossRef]

19. Rakić, S.; Povrenović, D.; Tešević, V.; Simić, M.; Maletić, R. Oak acorn, polyphenols and antioxidant activity in functional food. J. Food Eng. 2006, 74, 416-423. [CrossRef]

20. Rodríguez-Flores, S.M.; Escuredo, O.; Seijo, C.M. Assessment of Physicochemical and Antioxidant Characteristics of Quercus pyrenaica Honeydew Honeys. Food Chem. 2015, 166, 101-106. [CrossRef] [PubMed]

21. Moreno-Jimenez, M.R.; Trujillo-Esquivel, F.; Gallegos-Corona, M.A.; Reynoso-Camacho, R.; González-Laredo, R.F.; Gallegos-Infante, J.A.; Rocha-Guzmán, N.E.; Ramos-Gomez, M. Antioxidant, anti-inflammatory and anticarcinogenic activities of edible red oak (Quercus spp.) infusions in rat colon carcinogenesis induced by 1,2-dimethylhydrazine. Food Chem. Toxicol. 2015, 80, 144-153. [CrossRef] [PubMed]

22. McCune, L.M.; Johns, T. Antioxidant activity in medicinal plants associated with the symptoms of diabetes mellitus used by the Indigenous Peoples of the North American boreal forest. J. Ethnopharmacol. 2002, 82, 197-205. [CrossRef]

23. Diouf, P.N.; Stevanovic, T.; Cloutier, A. Study on chemical composition, antioxidant and anti-inflammatory activities of hot water extract from Picea mariana bark and its proanthocyanidin-rich fractions. Food Chem. 2009, 113, 897-902. [CrossRef]

24. Poussard, S.; Pires-Alves, A.; Diallo, R.; Dupuy, J.-W.; Dargelos, E. A Natural Antioxidant Pine Bark Extract, Oligopin(R), Regulates the Stress Chaperone HSPB1 in Human Skeletal Muscle Cells: A Proteomics Approach. Phyther. Res. 2013, 27, 1529-1535. [CrossRef] [PubMed] 
25. Scalbert, A.; Monties, B.; Janin, G. Tannins in Wood: Comparison of Different Estimation Methods. J. Agric. Food Chem. 1989, 37, 1324-1329. [CrossRef]

26. Brighente, I.M.C.; Dias, M.; Verdi, L.G.; Pizzolatti, M.G. Antioxidant Activity and Total Phenolic Content of Some Brazilian Species. Pharm. Biol. 2007, 45, 156-161. [CrossRef]

27. Council of Europe. European Pharmacopoeia, 4th ed.; European Directorate for the Quality of Medicines and Heald Care: Strausbourg, Francia, 2002; pp. 331-332.

28. Porter, L.J.; Hrstich, L.N.; Chan, B.G. The Conversion of Procyanidins and Prodelphinidins to Cyanidin and Delphinidin. Phytochemistry 1986, 26, 223-230. [CrossRef]

29. García-Pérez, M.-E.; Royer, M.; Duque-fernandez, A.; Diouf, P.N.; Stevanovic, T.; Pouliot, R. Antioxidant, toxicological and antiproliferative properties of Canadian polyphenolic extracts on normal and psoriatic keratinocytes. J. Ethnopharmacol. 2010, 132, 251-258. [CrossRef] [PubMed]

30. Nishikimi, M.; Rao, A.N.; Yagi, K. The Occurrence of Superoxide Anion in the Reaction of Reduced Phenazine Methosulfate and Molecular Oxygen. Biochem. Biophys. Res. Commun. 1972, 46, 849-854. [CrossRef]

31. Ruch, R.J.; Cheng, S.; Klaunig, J.E. Prevention of Cytotoxicity and Inhibition of Intercellular Communication by Antioxidant Catechins Isolated from Chinese Green Tea. Carcinogenesis 1989, 10, 1003-1008. [CrossRef] [PubMed]

32. Smirnoff, N.; Cumbes, Q.J. Hydroxyl radical scavenging activity of compatible solutes. Phytochemistry 1989, 28, 1057-1060. [CrossRef]

33. Rao, M.N.A. Nitric oxide scavenging by curcuminoids. J. Pharm. Pharmacol. 1997, 49, 105-107. [CrossRef]

34. López-Alarcón, C.; Lissi, E. Interaction of pyrogallol red with peroxyl radicals. A basis for a simple methodology for the evaluation of antioxidant capabilities. Free Radic. Res. 2005, 39, 729-736. [CrossRef] [PubMed]

35. Aruoma, O.I.; Halliwell, B. Action of hypochlorous acid on the antioxidant protective enzymes superoxide dismutase, catalase and glutathione peroxidase. Biochem. J. 1987, 248, 973-976. [CrossRef] [PubMed]

36. StatSoft, STATISTICA. 2007. Available online: http:/ / statistica.io (accessed on 22 June 2018).

37. Naima, R.; Oumam, M.; Hannache, H.; Sesbou, A.; Charrier, B.; Pizzi, A.; Charrier, F.; Bouhtoury, F. Comparison of the impact of different extraction methods on polyphenols yields and tannins extracted from Moroccan Acacia mollissima barks. Ind. Crops Prod. 2015, 70, 245-252. [CrossRef]

38. Ammon, H.P.; Wahl, M.A. Pharmacology of Curcuma longa. Planta Med. 1991, 57, 1-7. [CrossRef] [PubMed]

39. Natić, M.M.; Dabić, D.Č.; Papetti, A.; Fotirić, M.M.; Ognjanov, A.V.; Ljubojević, M.; Tešić, Ž.L. Analysis and characterisation of phytochemicals in mulberry (Morus alba L.) fruits grown in Vojvodina, North Serbia. Food Chem. 2015, 171, 128-136. [CrossRef] [PubMed]

40. Metrouh-Amir, H.; Duarte, C.M.M.; Maiza, F. Solvent effect on total phenolic contents, antioxidant, and antibacterial activities of Matricaria pubescens. Ind. Crops Prod. 2015, 67, 249-256. [CrossRef]

41. Quettier-Deleu, C.; Gressier, B.; Vasseur, J.; Dine, T.; Brunet, C.; Luyckx, M.; Cazin, M.; Cazin, J.C.; Bailleul, F.; Trotin, F. Phenolic compounds and antioxidant activities of buckwheat (Fagopyrum esculentum Moench) hulls and flour. J. Ethnopharmacol. 2000, 72, 35-42. [CrossRef]

42. Zhao, C.-F.; Lei, D.J.; Hao Song, G.; Zhang, H.; Xu, H.; Yu, L.J. Characterisation of water-soluble proanthocyanidins of Pyracantha fortuneana fruit and their improvement in cell bioavailable antioxidant activity of quercetin. Food Chem. 2015, 169, 484-491. [CrossRef] [PubMed]

(C) 2018 by the authors. Licensee MDPI, Basel, Switzerland. This article is an open access article distributed under the terms and conditions of the Creative Commons Attribution (CC BY) license (http:/ / creativecommons.org/licenses/by/4.0/). 